\title{
Impact of preoperative anemia on relapse and survival in breast cancer patients
}

\author{
YingJun Zhang ${ }^{1 \dagger}$, YuYang Chen ${ }^{2 \dagger}$, DongTai Chen ${ }^{1 \dagger}$, Yu Jiang ${ }^{1}$, Wan Huang ${ }^{1}$, HanDong Ouyang ${ }^{1}$, Wei Xing ${ }^{1}$, \\ Musheng Zeng ${ }^{3}$, XiaoMing $\mathrm{Xie}^{4}$ and Weian Zeng ${ }^{1 *}$
}

\begin{abstract}
Background: Previous studies have shown that preoperative anemia is correlated with the prognoses of various solid tumors. This study was performed to determine the effect of preoperative anemia on relapse and survival in patients with breast cancer.

Methods: A total of 2960 patients with breast cancer who underwent surgery between 2002 and 2008 at the Sun Yat-sen University Cancer Center (Guangzhou, PR China) were evaluated in a retrospective analysis. A total of 2123 qualified patients were divided into an anemic group [hemoglobin $(\mathrm{Hb})<12.0 \mathrm{~g} / \mathrm{dL}, \mathrm{N}=535)$ ] and a nonanemic group ( $\mathrm{Hb} \geq 12.0 \mathrm{~g} / \mathrm{dL}, \mathrm{N}=1588$ ). The effects of anemia on local relapse-free survival (LRFS), lymph node metastasis-free survival (LNMFS), distant metastasis-free survival (DMFS), relapse-free survival (RFS), and overall survival (OS) were assessed using Kaplan-Meier analysis. Independent prognostic factors were identified in the final multivariate Cox proportional hazards regression model.

Results: Among the 2123 women who qualified for the analysis, 535 (25.2\%) had a Hb level $<12.0 \mathrm{~g} / \mathrm{dL}$. The KaplanMeier curves showed that anemic patients had worse LRFS, LNMFS, DMFS, RFS, and OS than nonanemic patients, even in the same clinical stage of breast cancer. Cox proportional hazards regression model indicated that preoperative anemia was an independent prognostic factor of LRFS, LNMFS, DMFS, RFS, and OS for patients with breast cancer.
\end{abstract}

Conclusions: Preoperative anemia was independently associated with poor prognosis of patients with breast cancer.

Keywords: Preoperative anemia, Breast cancer, Relapse, Survival, Hypoxia

\section{Background}

Anemia is a common complication in patients with cancer. It has been reported that between $30-90 \%$ of patients with cancer have anemia [1]. Most studies have found that pre-treatment anemia is associated with a worse prognosis in cancer patients [2-5]. In a meta-analysis, anemic patients with lung cancer, cervicouterine carcinoma, head and neck cancer, prostate cancer, lymphoma, and multiple myeloma had shorter survival times than those without anemia. The overall estimated increase in risk was $65 \%$ (54-77\%) [6]. Preoperative anemia, even mild anemia, was independently associated with an increased risk of 30-day

\footnotetext{
* Correspondence: zengwa@mail.sysu.edu.cn

${ }^{\dagger}$ Equal contributors

'Anesthesiology Department, State Key Laboratory in South China, Sun Yat-Sen University Cancer Center, 651 Dongfeng East Road, Guangzhou, PR China

Full list of author information is available at the end of the article
}

morbidity and mortality in patients undergoing major noncardiac surgery [7].

Breast cancer is one of the most common carcinomas worldwide among women. Tumor size, nodal status, histological grade, lymphovascular invasion (LVI), gene profile and Human Epidermal Growth Factor Receptor-2 (HER-2)-positivity are strong prognostic factors of breast cancer [8-10]. Although $41-82 \%$ of breast cancer patients develop anemia before surgery, [1] few studies have explored the effects of preoperative anemia on the prognosis of breast cancer. Whether preoperative anemia has a significant adverse impact on relapse or survival in breast cancer patients is still controversial $[11,12]$.

In this study, we aimed to determine the effects of preoperative anemia on relapse (local relapse, lymph node metastasis, distant metastasis, and overall relapse) and survival (local relapse-free survival, lymph node metastasis-free survival, distant metastasis-free survival, relapse-free survival, 
and overall survival) in patients undergoing breast cancer surgery.

\section{Methods}

A total of 2960 patients with breast cancer who underwent surgery between 2002 and 2008 at the Sun Yat-sen University Cancer Center (Guangzhou, PR China) were evaluated in a retrospective analysis. This study was approved by the ethics committee of the Sun Yat-sen University Cancer Center. No consent from patients was needed.

We defined the preoperative blood hemoglobin $(\mathrm{Hb})$ concentration as the last $\mathrm{Hb}$ measurement before the index operation. We also collected other clinical data for subsequent analysis, including age, tumor type, tumor $(\mathrm{T})$ and nodal $(\mathrm{N})$ status, histological grade, estrogen receptor (ER) and progesterone receptor (PR) status, Human Epidermal Growth Factor Receptor-2 (Her-2) status, body mass index (BMI), menopausal status, type of surgery, and the use of chemotherapy, radiotherapy, endocrinotherapy, or targeted therapy. Patients with inadequate information, $\mathrm{T}_{0}$ stage cancer, metastases or inoperable tumors, as well as those treated with neoadjuvant chemotherapy or lost to follow-up were excluded from this analysis. Finally, 2123 patients were enrolled (Figure 1). We defined preoperative anemia as $\mathrm{Hb}<12.0 \mathrm{~g} / \mathrm{dL}$ and mild anemia as $9.0 \leq \mathrm{Hb}<12.0 \mathrm{~g} / \mathrm{dL}$ according to the World Health Organization (WHO) limits for $\mathrm{Hb}$. The patients were divided into two groups based on this definition: the anemic patients group $(\mathrm{Hb}<12.0 \mathrm{~g} / \mathrm{dL})$ and the nonanemic patient group $(\mathrm{Hb} \geq 12.0 \mathrm{~g} / \mathrm{dL})$.
We defined local relapse-free survival (LRFS) as the duration from the surgery date to the date when local relapse was diagnosed. Lymph node metastasis-free survival (LNMFS) was defined as the duration from the surgery date to the date when lymph node metastasis was diagnosed. Distant metastasis-free survival (DMFS) was defined as the duration from the surgery date to the date when distant metastasis was diagnosed. Relapse-free survival (RFS) was defined as the duration from the surgery date to the date when any relapse was diagnosed and overall survival (OS) as the duration from the surgery date to the date of death or the last follow-up.

The clinical stages of breast cancer were performed according to the American Joint Committee on Cancer (AJCC) staging system [13]. Stage I included $\mathrm{T}_{1}, \mathrm{~N}_{0}, \mathrm{M}_{0}$, stage II included IIA $\left(\mathrm{T}_{0-1}, \mathrm{~N}_{1}, \mathrm{M}_{0}\right.$ or $\left.\mathrm{T}_{2}, \mathrm{~N}_{0}, \mathrm{M}_{0}\right)$ and IIB $\left(T_{2}, N_{1}, M_{0}\right.$ or $\left.T_{3}, N_{0}, M_{0}\right)$ and stage III included IIIA $\left(\mathrm{T}_{0-2}, \mathrm{~N}_{2}, \mathrm{M}_{0}\right.$ or $\left.\mathrm{T}_{3}, \mathrm{~N}_{1-2}, \mathrm{M}_{0}\right)$, IIIB $\left(\mathrm{T}_{4}, \mathrm{~N}_{0-2}, \mathrm{M}_{0}\right)$ and IIIC (any T, $\mathrm{N}_{3}, \mathrm{M}_{0}$ ). Stage IV was not considered because the patients with metastases were excluded.

\section{Statistical analysis}

Patients' characteristics (frequency distributions) were analyzed using the $X^{2}$ test (chi-squared test). Spearman rank correlation coefficients of risk factors for both anemia and nonanemia groups were determined. We also used the $x^{2}$ test to compare the local relapse, lymph node metastasis, distant metastasis, overall relapse, and mortality rates between the two groups. The comparison of LRFS, LNMFS, DMFS, RFS, and OS between anemic

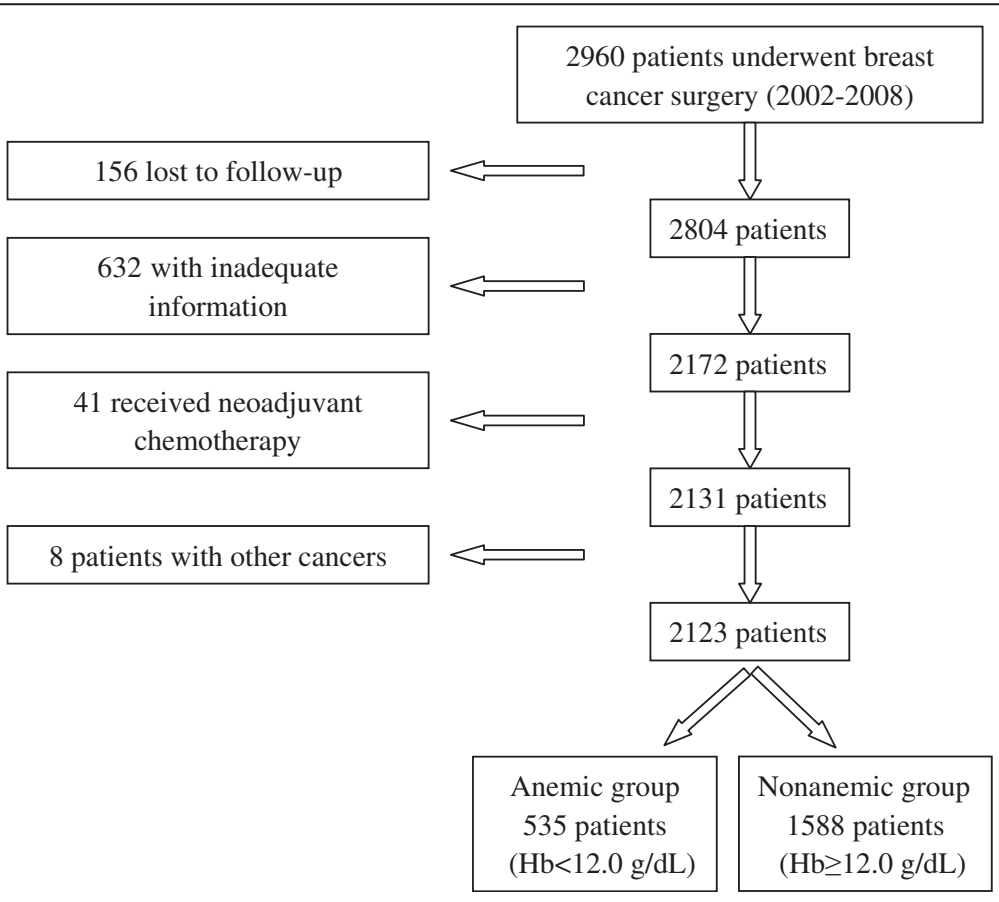

Figure 1 Flow chart of the patient grouping. 
Table 1 Clinical characteristics of patient by anemia status

\begin{tabular}{|c|c|c|c|c|c|}
\hline & $N=2123(\%)$ & $\begin{array}{c}\mathrm{Hb}<12 \mathrm{~g} / \mathrm{dL} \\
n=535(25.2 \%)\end{array}$ & $\begin{array}{c}\mathrm{Hb} \geq 12 \mathrm{~g} / \mathrm{dL} \\
n=1588(74.8 \%)\end{array}$ & $x^{2}$ & $P$ \\
\hline \multicolumn{6}{|l|}{ Age } \\
\hline$\leq 50$ & $1384(65.2)$ & $359(67.1)$ & $1025(64.5)$ & 1.152 & 0.283 \\
\hline$>50$ & 739 (34.8) & $176(32.9)$ & $563(35.5)$ & & \\
\hline \multicolumn{6}{|l|}{ Tumor type } \\
\hline Invasive ductal carcinoma & 1944 (91.6) & $503(94.0)$ & $1441(90.7)$ & 5.561 & 0.018 \\
\hline Other & $179(8.4)$ & $32(6.0)$ & $147(9.3)$ & & \\
\hline \multicolumn{6}{|l|}{ Tumor stage } \\
\hline $\mathrm{T} 1$ & $703(33.1)$ & $146(27.3)$ & $557(35.1)$ & 32.458 & $<0.001$ \\
\hline $\mathrm{T} 2$ & $1146(54.0)$ & $284(53.1)$ & $862(54.3)$ & & \\
\hline $\mathrm{T} 3$ and $\mathrm{T} 4$ & $274(12.9)$ & $105(19.6)$ & 169 (10.6) & & \\
\hline \multicolumn{6}{|l|}{ N stage } \\
\hline No & $1185(55.8)$ & $250(46.7)$ & $935(58.8)$ & 38.534 & $<0.001$ \\
\hline N1 & $603(28.4)$ & $159(29.7)$ & $444(28.0)$ & & \\
\hline N2 & $211(9.9)$ & $78(14.6)$ & $133(8.4)$ & & \\
\hline N3 & $124(5.8)$ & $48(9.0)$ & $76(4.8)$ & & \\
\hline \multicolumn{6}{|l|}{ Histologic grading } \\
\hline G1G2 or Gx & $1680(79.1)$ & $425(79.4)$ & $1255(79.0)$ & 0.041 & 0.840 \\
\hline G3 & $443(20.9)$ & $110(20.6)$ & $333(21.0)$ & & \\
\hline \multicolumn{6}{|l|}{ ER } \\
\hline Negative & $846(39.8)$ & $226(42.3)$ & $620(39.1)$ & 6.385 & 0.041 \\
\hline Positive & $683(32.2)$ & $182(34.0)$ & $501(31.5)$ & & \\
\hline Strongly positive & $594(28.0)$ & $127(23.7)$ & $467(29.4)$ & & \\
\hline \multicolumn{6}{|l|}{$P R$} \\
\hline Negative & $654(30.8)$ & $168(31.4)$ & $486(30.6)$ & 8.078 & 0.018 \\
\hline Positive & $906(42.7)$ & $249(46.5)$ & $657(41.4)$ & & \\
\hline Strongly positive & $563(26.5)$ & $118(22.1)$ & $445(28.0)$ & & \\
\hline \multicolumn{6}{|l|}{ HER-2 } \\
\hline Negative & $1067(50.3)$ & $249(46.5)$ & $818(51.5)$ & 10.315 & 0.006 \\
\hline Positive & $633(29.8)$ & $154(28.8)$ & $479(30.2)$ & & \\
\hline Strongly positive & $423(19.9)$ & $132(24.7)$ & $291(18.3)$ & & \\
\hline \multicolumn{6}{|l|}{ BMI } \\
\hline Low $(<18.5)$ & $151(7.1)$ & $47(8.8)$ & $104(6.6)$ & 25.980 & $<0.001$ \\
\hline Normal (18.5-22.9) & $929(43.8)$ & $276(51.6)$ & $653(41.1)$ & & \\
\hline High (>22.9) & $1043(49.1)$ & $212(39.6)$ & $831(52.3)$ & & \\
\hline \multicolumn{6}{|l|}{ Menopause } \\
\hline No & $1318(62.1)$ & $352(65.8)$ & $966(60.8)$ & 4.188 & 0.041 \\
\hline Yes & $805(37.9)$ & $183(34.2)$ & $622(39.2)$ & & \\
\hline \multicolumn{6}{|l|}{ Type of surgery } \\
\hline Modified radical mastectomy & $2092(98.5)$ & $531(99.3)$ & $1561(98.3)$ & 2.524 & 0.112 \\
\hline Breast-conserving surgery & $31(1.5)$ & $4(0.7)$ & $27(1.7)$ & & \\
\hline
\end{tabular}




\begin{tabular}{|c|c|c|c|c|c|}
\hline \multicolumn{6}{|c|}{ Chemotherapy } \\
\hline No & 381 (17.9) & 89 (16.6) & $292(18.4)$ & \multirow[t]{2}{*}{0.835} & \multirow[t]{2}{*}{0.361} \\
\hline Yes & $1742(82.1)$ & $446(83.4)$ & $1296(81.6)$ & & \\
\hline \multicolumn{6}{|c|}{ Radiotherapy } \\
\hline No & 1842 (86.8) & $452(84.5)$ & $1390(87.5)$ & \multirow[t]{2}{*}{3.232} & \multirow[t]{2}{*}{0.072} \\
\hline Yes & $281(13.2)$ & $83(15.5)$ & 198 (12.5) & & \\
\hline \multicolumn{6}{|c|}{ Hormonal therapy } \\
\hline No & $1366(64.3)$ & 347 (64.9) & 1019 (64.2) & \multirow[t]{2}{*}{0.083} & \multirow[t]{2}{*}{0.773} \\
\hline Yes & 757 (35.7) & $188(35.1)$ & 569 (35.8) & & \\
\hline \multicolumn{6}{|c|}{ Targeted therapy } \\
\hline No & 2109 (99.3) & $530(99.1)$ & 1579 (99.4) & \multirow[t]{2}{*}{-} & \multirow[t]{2}{*}{$0.361^{a}$} \\
\hline Yes & $14(0.7)$ & $5(0.9)$ & $9(0.6)$ & & \\
\hline
\end{tabular}

and nonanemic groups was performed using KaplanMeier analysis with the log-rank test. Multivariate Cox proportional hazards regression model with forward stepwise approach was constructed to identify independent prognostic factors. Age, tumor type, T-status, N-status, histologic grade, ER, PR, HER-2, BMI grade, menopause, type of surgery, anemia, sequential treatment after surgery (chemotherapy, radiotherapy, hormonal therapy, and targeted therapy) were predictive variables in the model. All statistical analyses were performed with SPSS (Statistical Package for the Social Sciences, IBM, NY, USA) version 16.0 software. A $P$ value $<0.05$ was considered statistically significant.

\section{Results}

Among a total of 2123 female patients qualified for the analysis, $535(25.2 \%)$ had a $\mathrm{Hb}$ level $<12.0 \mathrm{~g} / \mathrm{dL}$. The median age of the patients was 47.0 (range, 22-91) years. There were 484 patients in stage I, 1198 in stage II, and 441 in stage III, and the corresponding number of anemic patients at each stage was $89(18.4 \%), 283(23.6 \%)$, and $163(37.0 \%)$, respectively. Overall, $15.8 \%$ of the patients received locoregional radiotherapy, and $82.1 \%$ received adjuvant chemotherapy. Patient characteristics are shown in Table 1.

The relation between $\mathrm{Hb}$ levels and various risk factors was examined by Spearman rank correlation coefficients. As shown in Table 2, we found that there was a significant positive correlation between $\mathrm{Hb}$ levels and BMI, and a negative correlation with $\mathrm{T}$ - and $\mathrm{N}$-status and clinical stages.

After a median follow-up time of 67 months, 61 patients (2.9\%) underwent local relapse, 105 (4.9\%) had lymph node metastases, and 269 (12.7\%) had distant metastases among 2123 breast cancer patients. Local relapse was diagnosed in $7.3 \%$ of anemic patients versus
$1.4 \%$ of nonanemic patients $(P<0.001)$. For lymph node metastasis, distant metastasis, and any relapse, the percentages were $12.1 \%$ versus $2.5 \%(P<0.001), 26.7 \%$ versus $7.9 \%(P<0.001)$ and $38.7 \%$ versus $9.9 \%(P<0.001)$, respectively. Mortality was $24.5 \%$ in anemic group versus $7.7 \%$ in nonanemic group $(P<0.001)$ (Table 3$)$. The relapse rate and mortality were significantly different between the anemic and nonanemic groups.

In the univariate analysis, LRFS, LNMFS, DMFS, RFS, and OS were significantly shorter in anemic patients than those in nonanemic patients $(P<0.001$ for all) (Figure 2). Additionally, stratified analysis by different clinical stages (stages I to III) of breast cancer showed that LRFS, LNMFS, DMFS, RFS and OS were all significantly shorter in anemic

Table 2 Spearman's rank correlation of the hemoglobin levels and various clinical characteristics

\begin{tabular}{ccc}
\hline & Hb & $\boldsymbol{P}$ \\
\hline Age & 0.035 & 0.101 \\
Tumor type & 0.014 & 0.509 \\
T stage & -0.078 & $<0.001$ \\
N stage & -0.051 & 0.019 \\
Clinical stage & -0.085 & $<0.001$ \\
Histologic grading & 0.010 & 0.653 \\
ER & 0.029 & 0.181 \\
PR & 0.016 & 0.460 \\
HER-2 & -0.035 & 0.103 \\
BMl & 0.134 & $<0.001$ \\
Chemotherapy & -0.025 & 0.242 \\
Radiotherapy & -0.014 & 0.521 \\
Hormonal therapy & 0.002 & 0.912 \\
Targeted therapy & -0.034 & 0.115 \\
\hline Abbriansions
\end{tabular}

Abbreviations: $\mathrm{Hb}$ hemoglobin, $E R$ estrogen receptor, $P R$ progesterone receptor, HER-2 Human Epidermal Growth Factor Receptor-2, BMI body mass index. 
Table 3 Prevalence of relapses and deaths in patients with and without anemia

\begin{tabular}{|c|c|c|c|c|c|}
\hline & $N=2123$ & $\begin{array}{c}\mathrm{Hb}<12 \mathrm{~g} / \mathrm{dL} \\
n=535(\%)\end{array}$ & $\begin{array}{l}\mathrm{Hb} \geq 12 \mathrm{~g} / \mathrm{dL} \\
n=1588(\%)\end{array}$ & $x^{2}$ & $P$ \\
\hline \multicolumn{6}{|c|}{ Local relapse } \\
\hline No & 2062 & $496(92.7)$ & 1566 (98.6) & 49.989 & $<0.001$ \\
\hline Yes & 61 & $39(7.3)$ & $22(1.4)$ & & \\
\hline \multicolumn{6}{|c|}{ Lymph node metastasis } \\
\hline No & 2018 & $470(87.9)$ & $1548(97.5)$ & 78.950 & $<0.001$ \\
\hline Yes & 105 & $65(12.1)$ & $40(2.5)$ & & \\
\hline \multicolumn{6}{|c|}{ Distant metastasis } \\
\hline No & 1854 & $392(73.3)$ & $1462(92.1)$ & 127.7 & $<0.001$ \\
\hline Yes & 269 & $143(26.7)$ & $126(7.9)$ & & \\
\hline \multicolumn{6}{|c|}{ Any relapse } \\
\hline No & 1758 & $328(61.3)$ & $1430(90.1)$ & 232.2 & $<0.001$ \\
\hline Yes & 365 & $207(38.7)$ & $158(9.9)$ & & \\
\hline \multicolumn{6}{|l|}{ Death } \\
\hline No & 1869 & $404(75.5)$ & $1465(92.3)$ & 106.5 & $<0.001$ \\
\hline Yes & 254 & $131(24.5)$ & $123(7.7)$ & & \\
\hline
\end{tabular}

Abbreviation: $H b$ hemoglobin.

patients (Figures 3, 4 and 5). Among the 2123 anemic patients, 2104 had mild anemia $(9.0 \leq \mathrm{Hb}<12.0 \mathrm{~g} / \mathrm{dL})$. Survivals were also significantly shorter even in patients with mild anemia (Figure 6).

Multivariate analysis with all relevant prognostic factors in a Cox proportional hazards regression model showed that preoperative anemia was a significant prognostic factor in breast cancer patients (Table 4). T-status $\left(\geq \mathrm{T}_{3}\right)$, $\mathrm{N}$-status $\left(\mathrm{N}_{1}, \mathrm{~N}_{2}\right)$, strongly positive PR status and HER-2 positivity were significantly associated with LRFS, and anemic patients had a 4.939-fold increased relative risk of developing local relapse compared with nonanemic patients. Only the $\mathrm{N}$-status $\left(\mathrm{N}_{1}, \mathrm{~N}_{2}\right)$ was significantly associated with LNMFS, with a 5.160-fold increased relative risk of developing lymph node metastasis for anemic patients compared with nonanemic patients. With respect to DMFS and OS, T-status $\left(\geq \mathrm{T}_{3}\right)$ and $\mathrm{N}$-status $\left(\mathrm{N}_{1}-\mathrm{N}_{3}\right)$ still had significant associations, and the relative risks of developing distant metastasis and death in the anemic group were 3.192-fold and 2.849-fold higher than those in the nonanemic group, respectively. For RFS, T-status $\left(\geq \mathrm{T}_{3}\right)$, N-status $\left(\mathrm{N}_{1}-\mathrm{N}_{3}\right)$, and strongly positive PR status were shown to be significant prognostic factors. Anemic patients had a 4.104-fold increased relative risk of developing any relapse compared with nonanemic patients.

\section{Discussion}

Preoperative anemia has been reported to be associated with poor prognosis in many types of tumors $[6,14]$. In our present study, a low preoperative Hb level was shown to be associated with local and distant relapses in breast cancer patients. Shorter survival was also observed in anemic patients. To the best of our knowledge, our study was the first to discover that preoperative $\mathrm{Hb}$ levels were associated with tumor $(\mathrm{T})$ and nodal $(\mathrm{N})$ status of breast cancer and BMI. Further, the most important study finding was that preoperative anemia was shown to be an independently prognostic factor for LRFS, LNMFS, DMFS, RFS, and OS in breast cancer patients, even in the same clinical stage or at lower stages.

Causes of anemia in cancer patients are multifactorial and can be considered as results of cancer invasion, induced by treatment (after radiotherapy or chemotherapy), or chronic kidney disease [15]. Among the three factors mentioned above, the first one is the largest contributor. Cancer itself can cause or exacerbate anemia in several ways [16]. Cancer cells may suppress hematopoiesis via bone marrow infiltration directly. They also generate cytokines that lead to functional iron deficiency, which decreases the production and shorten the survival of red blood cells [17]. Also, chronic blood loss at tumor sites through cancer cells infiltration can exacerbate anemia. Other indirect effects include nutritional deficiencies of iron, folate, and vitamin B12 secondary to anorexia or hemolysis by immune-mediated antibodies. For the factors mentioned above, it is plausible that preoperative anemia is more frequent in higher clinical stages and low BMI in association with malnutrition.

Many studies supported that pre-treatment $\mathrm{Hb}$ levels during adjuvant or neoadjuvant chemotherapy were related to the prognosis of breast cancer. However, few studies focused on the preoperative Hb levels $[12,18,19]$. 

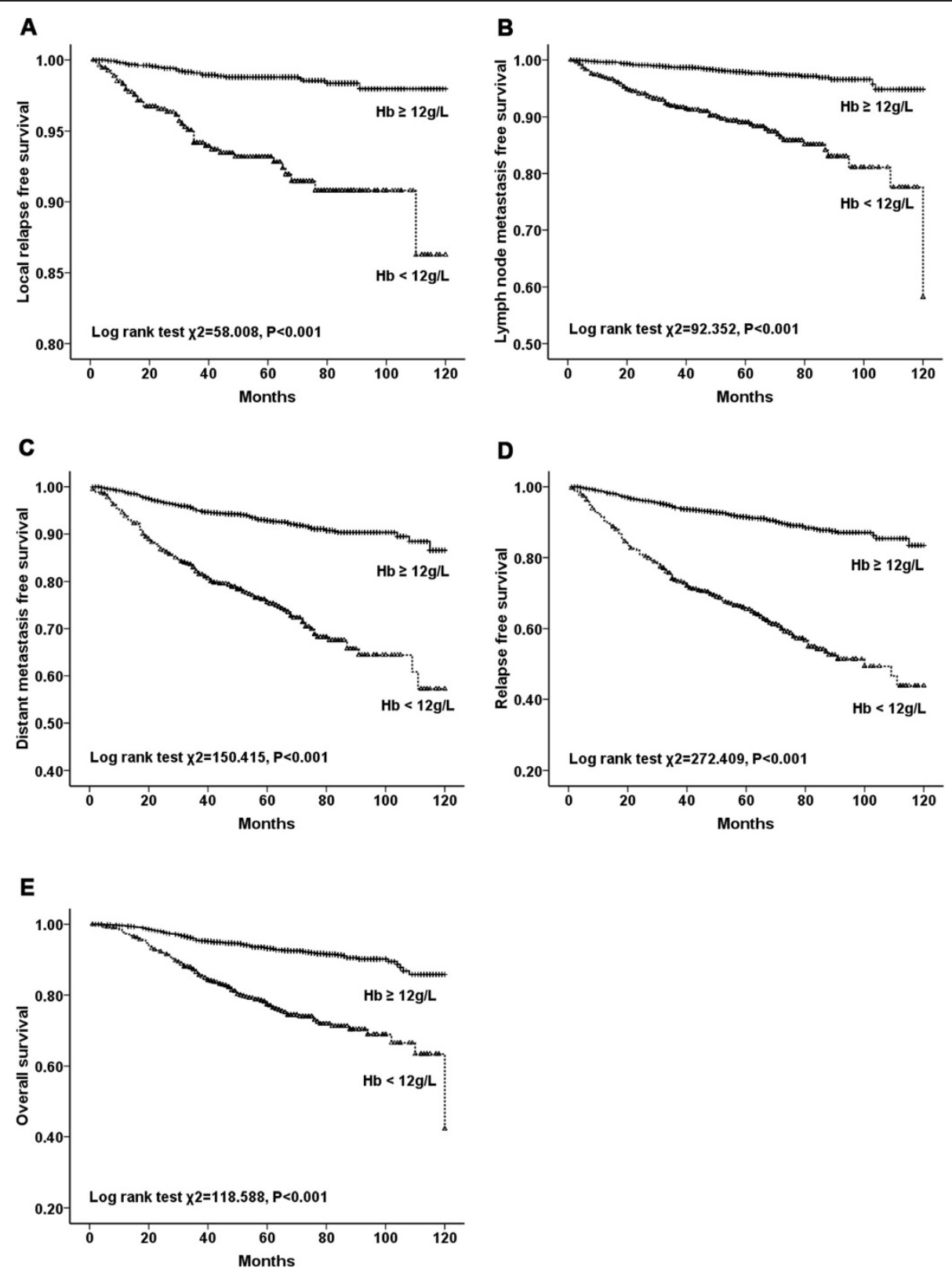

Figure 2 LRFS, LNMFS, DMFS, RFS, and OS of patients with and without anemia. A. LRFS for patients with $\mathrm{Hb} \geq 12 \mathrm{~g} / \mathrm{dL}$ versus $\mathrm{Hb}<12 \mathrm{~g} / \mathrm{dL}$. B. LNMFS for patients with $\mathrm{Hb} \geq 12 \mathrm{~g} / \mathrm{dL}$ versus $\mathrm{Hb}<12 \mathrm{~g} / \mathrm{dL}$. C. DMFS for patients with $\mathrm{Hb} \geq 12 \mathrm{~g} / \mathrm{dL}$ versus $\mathrm{Hb}<12 \mathrm{~g} / \mathrm{dL}$. D. RFS for patients with $\mathrm{Hb} \geq 12 \mathrm{~g} / \mathrm{dL}$ versus $\mathrm{Hb}<12 \mathrm{~g} / \mathrm{dL}$. E. OS for patients with $\mathrm{Hb} \geq 12 \mathrm{~g} / \mathrm{dL}$ versus $\mathrm{Hb}<12 \mathrm{~g} / \mathrm{dL}$.

Kandemir et al. reported that preoperative anemia was an independent risk factor of disease-free survival and overall survival in 336 early-stage breast cancer patients [11]. Our results not only supported their conclusion but also showed that preoperative anemia was associated with local relapse-free survival, lymph node metastasisfree survival, and distant metastasis-free survival in a larger cohort.

There are several possible mechanisms by which anemia may reduce survival, and hypoxia is the most important one. Anemia can reduce the capacity of the blood to transport oxygen $\left(\mathrm{O}_{2}\right)$, further contributing to the development of hypoxia. Hypoxia is a common characteristic of locally advanced solid tumors that has been associated with greater recurrence, less locoregional control, diminished therapeutic responses, and lower overall and disease-free survival $[20,21]$. The association between the blood $\mathrm{Hb}$ concentration $(\mathrm{cHb})$ and the tumor oxygenation status has been examined [22-27]. The median $\mathrm{pO}_{2}$ values in breast cancer tumors are lower than those in the normal breast, which exponentially increase with increasing cHb values [28]. In normal breast tissue, the $\mathrm{O}_{2}$ tensions 

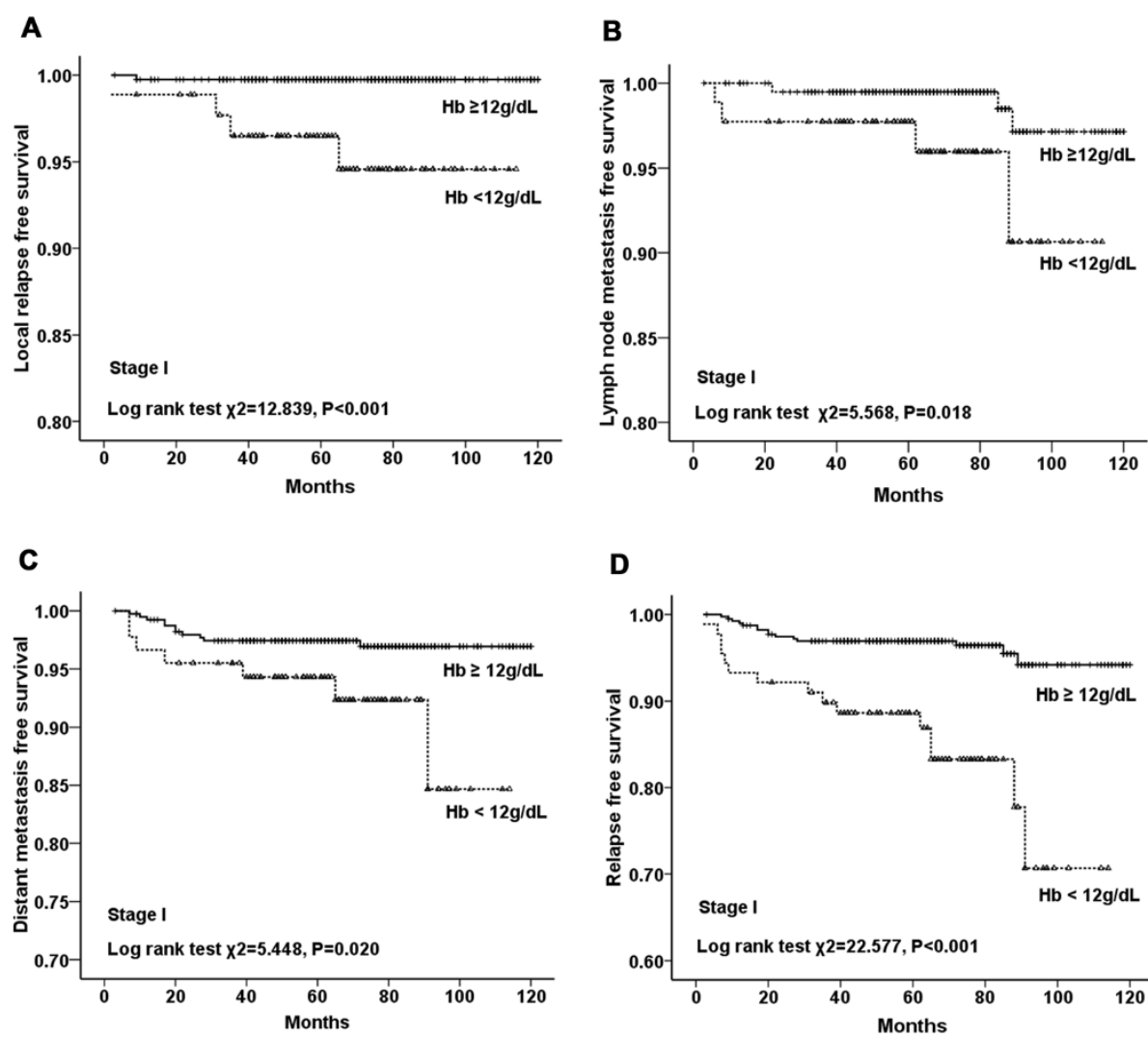

D

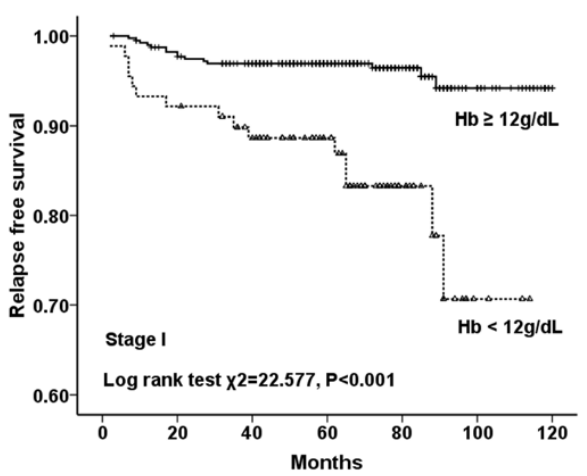

E

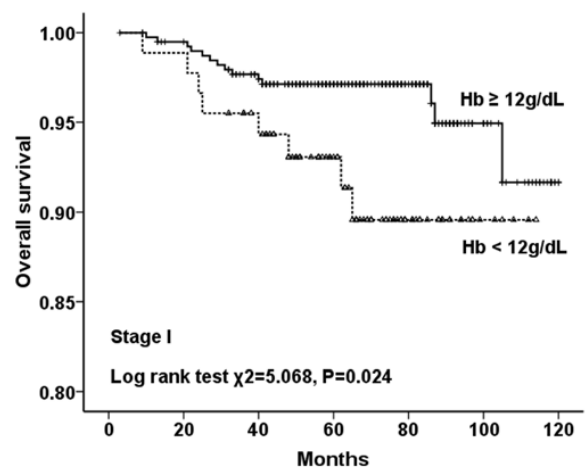

Figure 3 LRFS, LNMFS, DMFS, RFS, and OS of patients in stage I with and without anemia. A. LRFS for patients with $\mathrm{Hb} \geq 12 \mathrm{~g} / \mathrm{dL}$ versuS $\mathrm{Hb}<12 \mathrm{~g} / \mathrm{dL}$ in stage I. B. LNMFS for patients with $\mathrm{Hb} \geq 12 \mathrm{~g} / \mathrm{dL}$ versus $\mathrm{Hb}<12 \mathrm{~g} / \mathrm{dL}$ in stage I. C. DMFS for patients with $\mathrm{Hb} \geq 12 \mathrm{~g} / \mathrm{dL}$ versus $\mathrm{Hb}<12 \mathrm{~g} / \mathrm{dL}$ in stage I. D. RFS for patients with $\mathrm{Hb} \geq 12 \mathrm{~g} / \mathrm{dL}$ versus $\mathrm{Hb}<12 \mathrm{~g} / \mathrm{dL}$ in stage I. E. OS for patients with $\mathrm{Hb} \geq 12 \mathrm{~g} / \mathrm{dL}$ versus $\mathrm{Hb}<12 \mathrm{~g} / \mathrm{dL}$ in stage $\mathrm{I}$.

are approximately at a mean $\mathrm{pO}_{2}$ of $65 \mathrm{mmHg}$. However, in breast cancer tissue, the median $\mathrm{pO}_{2}$ is $28 \mathrm{mmHg}$. Further, nearly $60 \%$ of breast cancers contain hypoxic tissue areas with $\mathrm{pO}_{2}$ values $<2.5 \mathrm{mmHg}$ [29].

Hypoxia can lead to structural and functional abnormalities in the tumor microvasculature, an adverse diffusion geometry and tumor-related anemia result in a reduced $\mathrm{O}_{2}$ transport capacity of the blood [30]. A key regulator of this process is hypoxia-inducible factor-1 (HIF-1). HIF-1 is a molecular determinant that responds to hypoxia. Its expression increases as the pathologic stages progress, and it is higher in poorly differentiated lesions than in welldifferentiated lesions [31]. HIF-1 activity mediates angiogenesis [32-34], epithelial-mesenchymal transition [25], genetic mutations, resistance to apoptosis, and resistance to radiotherapy and chemotherapy [34] in regions of intratumoral hypoxia. More recent studies have suggested that HIF- $1 \alpha$ is a significant positive regulator of tumor progression, metastasis, and poor patient prognosis [26,32,33], and higher expression of HIF-1 $\alpha$ has been shown to 

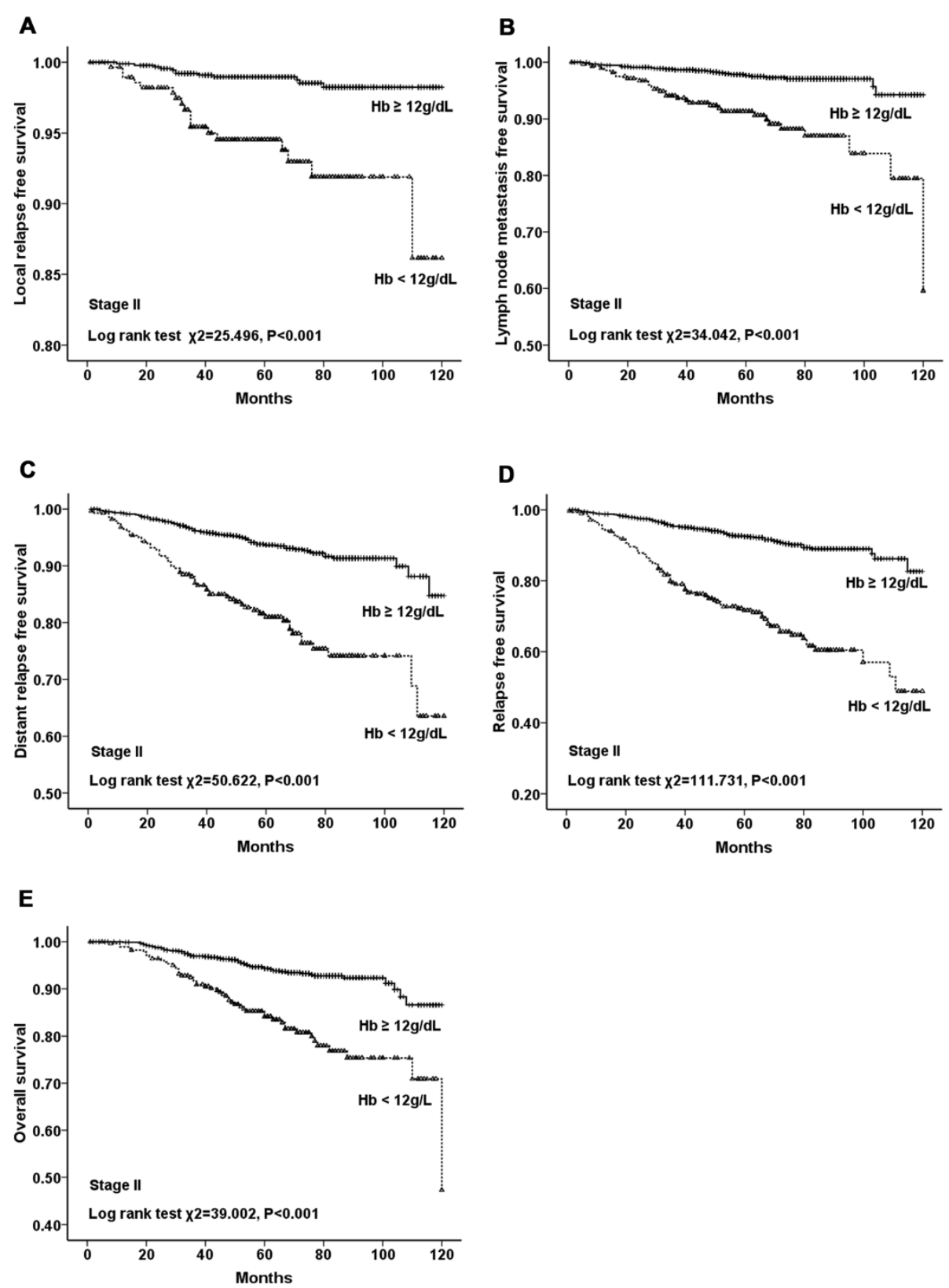

Figure 4 LRFS, LNMFS, DMFS, RFS, and OS for patients in stage II with and without anemia. A. LRFS for patients with $\mathrm{Hb} \geq 12 \mathrm{~g} / \mathrm{dL}$ versus $\mathrm{Hb}<12 \mathrm{~g} / \mathrm{dL}$ in stage II. B. LNMFS for patients with $\mathrm{Hb} \geq 12 \mathrm{~g} / \mathrm{dL}$ versus $\mathrm{Hb}<12 \mathrm{~g} / \mathrm{dL}$ in stage II. C. DMFS for patients with $\mathrm{Hb} \geq 12 \mathrm{~g} / \mathrm{dL}$ versus $\mathrm{Hb}<12 \mathrm{~g} / \mathrm{dL}$ in stage II. D. RFS for patients with $\mathrm{Hb} \geq 12 \mathrm{~g} / \mathrm{dL}$ versus $\mathrm{Hb}<12 \mathrm{~g} / \mathrm{dL}$ in stage II. E. OS for patients with $\mathrm{Hb} \geq 12 \mathrm{~g} / \mathrm{dL}$ versus $\mathrm{Hb}<12 \mathrm{~g} / \mathrm{dL}$ in stage II.

correlate with poorer survival in breast cancer patients $[35,36]$. This effect was independent of standard prognostic factors, such as tumor stage and nodal status [37]. Some results of our study may be attributed to hypoxia and HIF- $1 \alpha$ activity. It was interesting that preoperative $\mathrm{Hb}$ levels were negatively related to tumor $(\mathrm{T})$ and nodal (N) status of breast cancer, which were both traditional prognostic factors of breast cancer. However, anemia also impaired various survival outcomes independently even in the same clinical stage.

Although preoperative anemia was not related to the sequential postoperative treatment in our study, most of the data supported the notion that pretreatment anemia may influence the effects of sequential postoperative treatment. The reason may be that preoperative anemia contributes to hypoxia in cancer cells. There is increasing evidence 

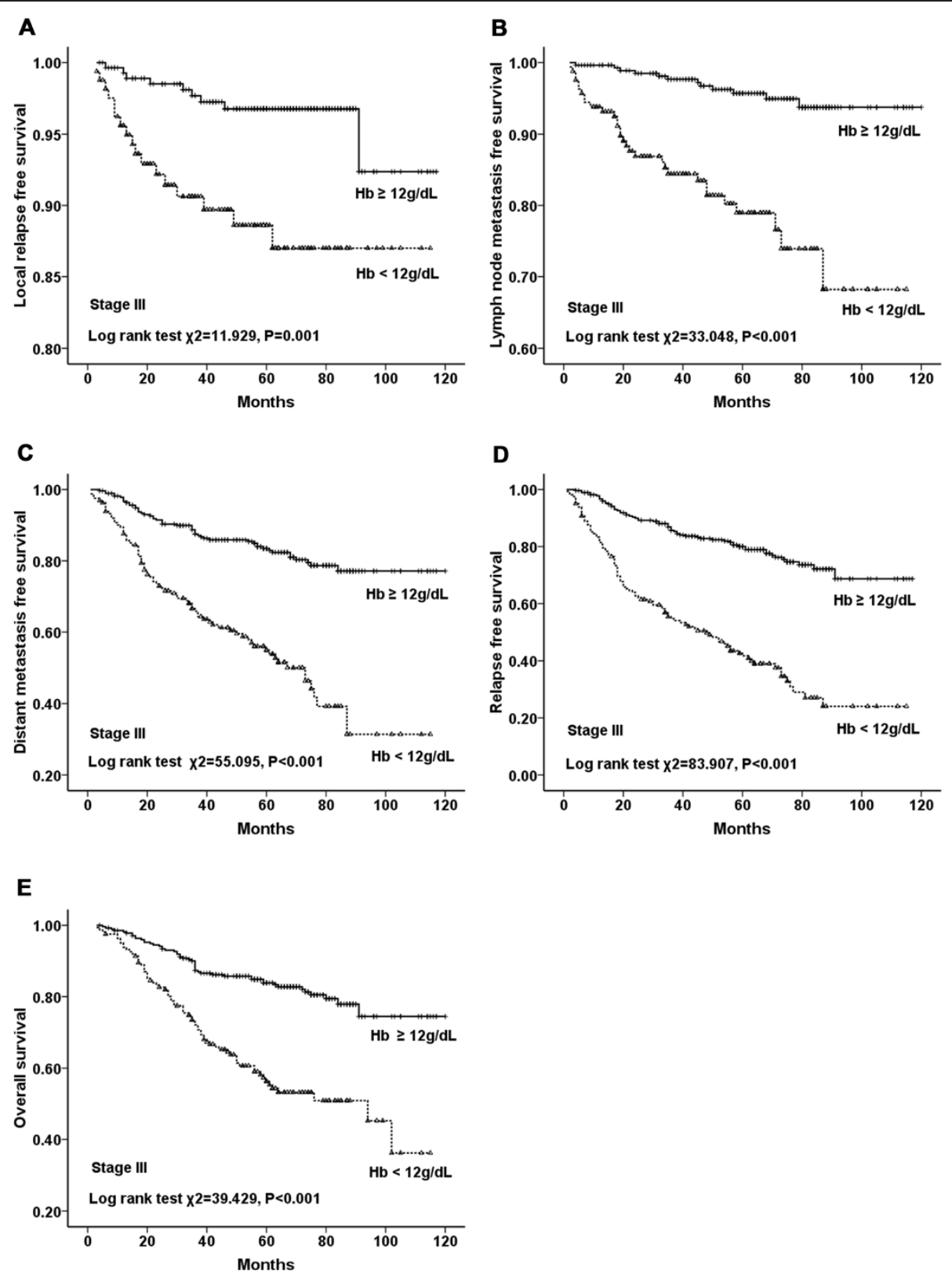

Figure 5 LRFS, LNMFS, DMFS, RFS, and OS for patients in stage III with and without anemia. A. LRFS for patients with $\mathrm{Hb} \geq 12 \mathrm{~g} / \mathrm{dL}$ versus $\mathrm{Hb}<12 \mathrm{~g} / \mathrm{dL}$ in stage III. B. LNMFS for patients with $\mathrm{Hb} \geq 12 \mathrm{~g} / \mathrm{dL}$ versus $\mathrm{Hb}<12 \mathrm{~g} / \mathrm{dL}$ in stage III. C. DMFS for patients with $\mathrm{Hb} \geq 12 \mathrm{~g} / \mathrm{dL}$ versus $\mathrm{Hb}<12 \mathrm{~g} / \mathrm{dL}$ in stage III. D. RFS for patients with $\mathrm{Hb} \geq 12 \mathrm{~g} / \mathrm{dL}$ versus $\mathrm{Hb}<12 \mathrm{~g} / \mathrm{dL}$ in stage III. E. OS for patients with $\mathrm{Hb} \geq 12 \mathrm{~g} / \mathrm{dL}$ versus $\mathrm{Hb}<12 \mathrm{~g} / \mathrm{dL}$ in stage III.

that hypoxic cancer cells are likely to be resistant to radiotherapy, chemotherapy, and targeted therapy. Thus, the potential for invasion, metastasis and patient mortality is increased further $[25-27,30]$. Hypoxia leads to therapeutic resistance directly through a lack of $\mathrm{O}_{2}$, which radiation and some chemotherapeutic drugs require to exert their cytotoxicity. Hypoxia also leads to resistance indirectly through changes in cellular metabolism, proliferation kinetics, the cell-cycle position, the hypoxia-driven proteome, and genome and clonal selection [21,27].

Although hypoxia may be a reasonable explanation for the association between anemia and survival of breast cancer, there was no direct evidence of hypoxia in cancer cells in our large population study. Emerging new tools that can measure the local $\mathrm{Hb}$ level and $\mathrm{O}_{2}$ tension directly in tumor tissues may solve this problem in the future. Our 

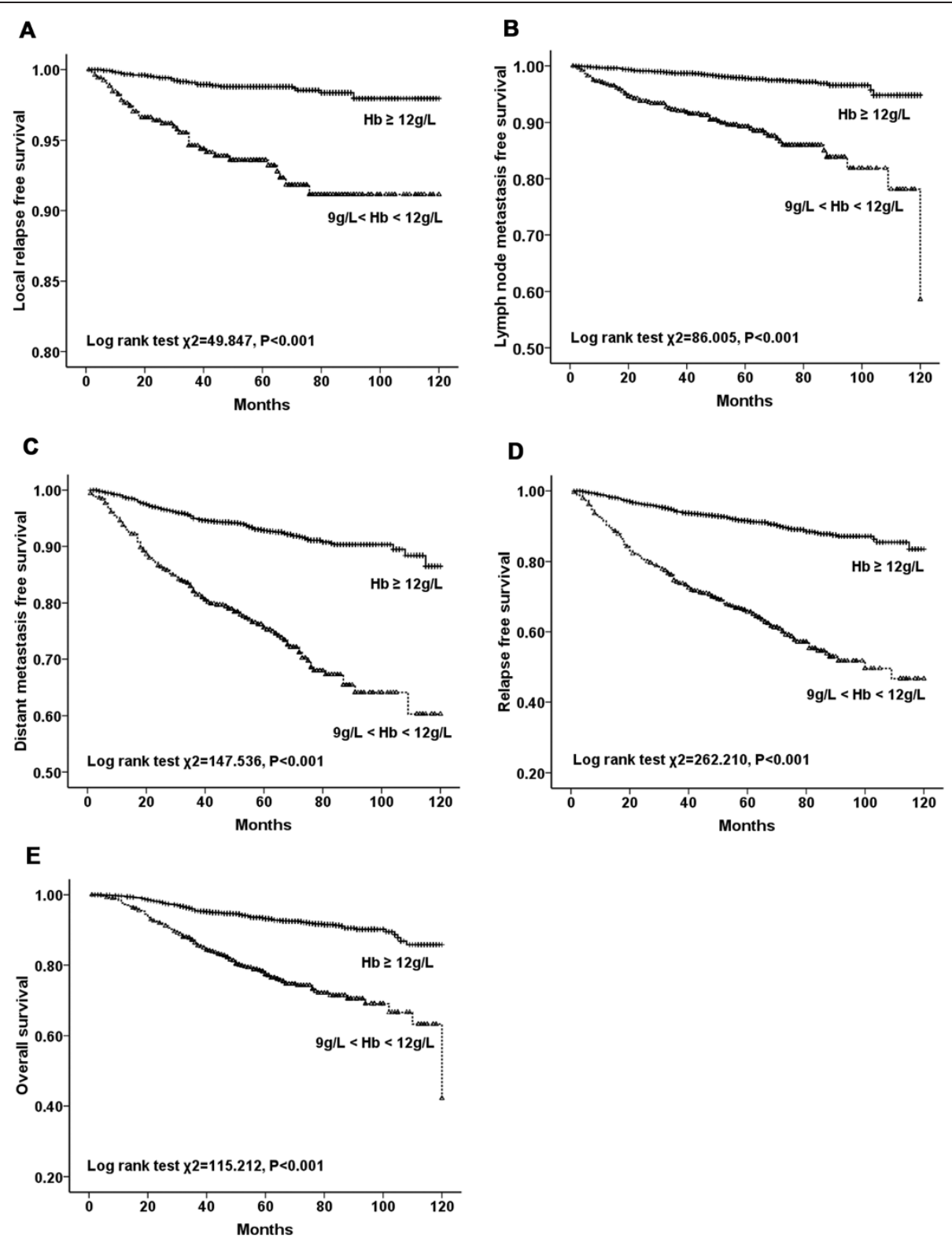

Figure 6 LRFS, LNMFS, DMFS, RFS, and OS for patients without anemia versus mild anemia. A. LRFS for patients with $\mathrm{Hb} \geq 12 \mathrm{~g} / \mathrm{dL}$ versus $9<\mathrm{Hb}<12 \mathrm{~g} / \mathrm{dL}$. B. LNMFS for patients with $\mathrm{Hb} \geq 12 \mathrm{~g} / \mathrm{dL}$ versus $9<\mathrm{Hb}<12 \mathrm{~g} / \mathrm{dL}$. C. DMFS for patients with $\mathrm{Hb} \geq 12 \mathrm{~g} / \mathrm{dL}$ versus $9<\mathrm{Hb}<12 \mathrm{~g} / \mathrm{dL}$. D. RFS for patients with $\mathrm{Hb} \geq 12 \mathrm{~g} / \mathrm{dL}$ versus $9<\mathrm{Hb}<12 \mathrm{~g} / \mathrm{dL}$. E. OS for patients with $\mathrm{Hb} \geq 12 \mathrm{~g} / \mathrm{dL}$ versus $9<\mathrm{Hb}<12 \mathrm{~g} / \mathrm{dL}$.

study provided a clue for further investigations to clarify the complex mechanisms of hypoxia in breast cancer.

Since preoperative anemia was associated with poor prognosis in breast cancer patients in our study, would patients benefit from anemia treatment preoperatively? Or could we improve the prognosis after administering treatment for anemia? The answer to this question is somewhat ambiguous because of the complexity of anemia. For most of patients with breast cancer without chemotherapy, preoperative anemia was caused by multiple etiologies, including blood loss, functional iron deficiency, erythropoietin deficiency secondary to renal disease, tumoral marrow involvement, well as other factors. Evaluation of anemia should be performed carefully before treatment because an unsuitable treatment might lead to adverse effects. The most common treatment options for anemic patients include iron therapy, red cell transfusion, and erythropoietic-stimulating agents. For iron therapy, nutritional status (iron, total iron binding capacity, ferritin, transferrin saturation, folate, and vitamin $B_{12}$ ) and renal function should be evaluated. Only absolute iron deficiency will benefit from intravenous or oral iron monotherapy $[38,39]$. Unfortunately the absence of data regarding the nutritional status and renal function of our patients impeded further analysis. 
Table 4 Multivariate analysis of prognostic factors for LRFS, LNMFS, DMFS, RFS, and OS

\begin{tabular}{|c|c|c|c|c|c|c|c|c|c|c|}
\hline & $\begin{array}{c}\text { LRFS } \\
\text { HR }(95 \% \mathrm{Cl})\end{array}$ & $\begin{array}{c}\text { LNMFS } \\
P\end{array}$ & $\begin{array}{c}\text { DMFS } \\
\text { HR }(95 \% \mathrm{Cl})\end{array}$ & $\begin{array}{c}\mathrm{RFS} \\
P\end{array}$ & $\begin{array}{c}\text { OS } \\
95 \% \mathrm{Cl}\end{array}$ & $P$ & $95 \% \mathrm{Cl}$ & $P$ & $95 \% \mathrm{Cl}$ & $P$ \\
\hline \multicolumn{11}{|l|}{ T stage } \\
\hline $\mathrm{T}_{1}$ & Ref & & NS & NS & Ref & & Ref & & Ref & \\
\hline $\mathrm{T}_{2}$ & $1.045(0.532-2.050)$ & 0.899 & NS & NS & $1.333(0.962-1.847)$ & 0.084 & $1.287(0.976-1.697)$ & 0.074 & $1.291(0.925-1.803)$ & 0.134 \\
\hline$\geq T_{3}$ & $2.676(1.267-5.653)$ & 0.010 & NS & NS & $1.983(1.347-2.920)$ & 0.001 & $2.021(1.455-2.807)$ & $<0.001$ & $2.020(1.371-2.975)$ & $<0.001$ \\
\hline \multicolumn{11}{|l|}{ N stage } \\
\hline$N_{0}$ & $\operatorname{Ref}$ & & Ref & & Ref & & Ref & & Ref & \\
\hline$N_{1}$ & $2.601(1.366-4.963)$ & 0.004 & $2.235(1.366-3.657)$ & 0.001 & $2.040(1.493-2.788)$ & $<0.001$ & $2.009(1.544-2.615)$ & $<0.001$ & $1.942(1.404-2.687)$ & $<0.001$ \\
\hline $\mathrm{N}_{2}$ & $2.708(1.122-6.534)$ & 0.027 & $3.742(2.058-6.805)$ & $<0.001$ & $3.484(2.358-5.147)$ & $<0.001$ & $3.016(2.152-4.225)$ & $<0.001$ & $4.200(2.854-6.181)$ & $<0.001$ \\
\hline $\mathrm{N}_{3}$ & $2.450(0.859-6.989)$ & 0.094 & $2.045(0.912-4.487)$ & 0.083 & $4.822(3.175-7.323)$ & $<0.001$ & $3.856(2.672-5.565)$ & $<0.001$ & $5.083(3.307-7.812)$ & $<0.001$ \\
\hline \multicolumn{11}{|l|}{ ER } \\
\hline Negative & Ref & & NS & NS & Ref & & Ref & & Ref & \\
\hline Positive & $0.525(0.261-1.057)$ & 0.071 & NS & NS & $0.670(0.479-0.937)$ & 0.019 & $0.726(0.547-0.965)$ & 0.027 & $0.845(0.598-1.194)$ & 0.340 \\
\hline Strongly positive & $0.340(0.144-0.803)$ & 0.014 & NS & NS & $0.804(0.537-1.206)$ & 0.292 & $0.757(0.534-1.074)$ & 0.119 & $0.566(0.360-0.890)$ & 0.014 \\
\hline \multicolumn{11}{|l|}{$P R$} \\
\hline Negative & Ref & & NS & NS & NS & NS & Ref & NS & NS & NS \\
\hline Positive & $1.709(0.826-3.535)$ & 0.149 & NS & NS & NS & NS & $1.409(1.066-1.861)$ & 0.016 & NS & NS \\
\hline Strongly positive & $2.989(1.236-7.228)$ & 0.015 & NS & NS & NS & NS & $0.899(0.611-1.322)$ & 0.588 & NS & NS \\
\hline \multicolumn{11}{|l|}{ HER-2 } \\
\hline Negative & Ref & & NS & NS & NS & NS & NS & NS & NS & NS \\
\hline Positive & $2.179(1.232-3.855)$ & 0.007 & NS & NS & NS & NS & NS & NS & NS & NS \\
\hline Strongly positive & $0.651(0.292-1.451)$ & 0.294 & NS & NS & NS & NS & NS & NS & NS & NS \\
\hline Hormonal therapy & NS & NS & $0.537(0.335-0.859)$ & 0.009 & NS & NS & $0.733(0.575-0.933)$ & 0.012 & $0.682(0.503-0.926)$ & 0.014 \\
\hline Anemia & $4.939(2.875-8.484)$ & $<0.001$ & $5.160(3.428-7.767)$ & $<0.001$ & $3.192(2.489-4.094)$ & $<0.001$ & $4.104(3.310-5.089)$ & $<0.001$ & $2.849(2.205-3.680)$ & $<0.001$ \\
\hline
\end{tabular}

Abbreviations: LRFS local relapse-free survival, LNMFS lymph node metastasis-free survival, DMFS distant metastasis-free survival, RFS relapse-free survival, OS overall survival, $E R$ estrogen receptor, $P R$ progesterone receptor, HER-2 Human Epidermal Growth Factor Receptor-2, HR hazard ration, Cl confidence interval, Ref: Reference group; NS: No significance. 
Red cell transfusion is an acceptable treatment option for anemic breast cancer patients, especially for those requiring rapid improvement of $\mathrm{Hb}$ levels. However, large-scale studies involving cancer patients found that red cell transfusion was associated with increased thrombosis risk as well as increased mortality risk [40]. Additionally, mild anemia accounted for 99\% anemic patients in this study; thus, transfusions might not be necessary. As for erythropoieticstimulating agent therapy, it was suitable only for patients receiving palliative, myelosuppressive chemotherapy with a $\mathrm{Hb}<10 \mathrm{~g} / \mathrm{dL}$ and without absolute iron deficiency [39]. Notably, there were few reports focusing on the relationship between preoperative $\mathrm{Hb}$ and prognosis. However, most treatments for anemia were derived from the prognostic outcomes of patients with chemotherapy-induced anemia. Thus, whether preoperative anemia and chemotherapyinduced anemia are both associated with poor prognosis of patients with breast cancer remains to be clarified. The question of what is the best approach for patients with preoperative anemia remains unanswered. Therefore, further studies will be needed to answer these questions.

\section{Conclusions}

Preoperative anemia is a negative prognostic factor for survival of patients with breast cancer. However, it still merits further experimental and clinical investigations.

\begin{abstract}
Abbreviations
LRFS: Local relapse free survival; LNMFS: Lymph node metastasis free survival; DMFS: Distance metastasis free survival; RFS: Relapse free survival; OS: Overall survival; LVI: Lymphovascular invasion; HER-2: Human epidermal growth factor receptor-2; Hb: Hemoglobin; TNM: Tumor-Node-Metastasis; ER: Estrogen receptor; PR: Progesterone receptor; BMI: Body mass index; WHO: World Health Organization; $\mathrm{CHb}$ : Blood hemoglobin concentration; HIF-1: Hypoxia-inducible factor-1.
\end{abstract}

\section{Competing interests}

The authors declare that they have no competing interests.

\section{Authors' contributions}

YJ Zhang carried out the design and drafted the manuscript. YY Chen performed the interpretation of the data and statistical analysis. DT Chen, $Y$ Jiang, W Huang, HD Ouyang and W Xing participated in acquisition of data. MS Zeng and XM Xie participated in the critical revision of the manuscript for important intellectual content. WA Zeng carried out the major design and funding support, and performed supervision and coordination with other departments. All authors read and approved the final manuscript.

\section{Acknowledgements}

This study was supported by the Natural Science Foundation of China (NSFC) (No. 81271246) and Doctoral program foundation of State Education Ministry No. (20120171110096).

\section{Author details}

${ }^{1}$ Anesthesiology Department, State Key Laboratory in South China, Sun Yat-Sen University Cancer Center, 651 Dongfeng East Road, Guangzhou, PR China. ${ }^{2}$ Department of Cardiology, Sun Yat-sen Memorial Hospital of Sun Yat-Sen University, Guangzhou, PR China. ${ }^{3}$ State Key Laboratory in South China, Sun Yat-Sen University Cancer Center, Guangzhou, PR China. ${ }^{4}$ Department of Breast Cancer, Sun Yat-Sen University Cancer Center, Guangzhou, PR China.
Received: 9 July 2014 Accepted: 4 November 2014

Published: 18 November 2014

\section{References}

1. Knight K, Wade S, Balducci L: Prevalence and outcomes of anemia in cancer: a systematic review of the literature. Am J Med 2004, 116(Suppl 7A):11S-26S.

2. Hu K, Harrison LB: Impact of anemia in patients with head and neck cancer treated with radiation therapy. Curr Treat Options Oncol 2005, 6(1):31-45.

3. Choi YS, Yi CM, Sin Jl, Ye GW, Shin IH, Lee TS: Impact of hemoglobin on survival of cervical carcinoma patients treated with concurrent chemoradiotherapy is dependent on lymph node metastasis findings by magnetic resonance imaging. Int J Gynecol Cancer 2006, 16(5):1846-1854.

4. Grogan M, Thomas GM, Melamed I, Wong FL, Pearcey RG, Joseph PK, Portelance L, Crook J, Jones KD: The importance of hemoglobin levels during radiotherapy for carcinoma of the cervix. Cancer 1999, 86(8):1528-1536.

5. Dunphy EP, Petersen IA, Cox RS, Bagshaw MA: The influence of initial hemoglobin and blood pressure levels on results of radiation therapy for carcinoma of the prostate. Int J Radiat Oncol Biol Phys 1989, 16(5):1173-1178.

6. Caro JJ, Salas M, Ward A, Goss G: Anemia as an independent prognostic factor for survival in patients with cancer: a systemic, quantitative review. Cancer 2001, 91(12):2214-2221.

7. Musallam KM, Tamim HM, Richards T, Spahn DR, Rosendaal FR, Habbal A, Khreiss M, Dahdaleh FS, Khavandi K, Sfeir PM, Soweid A, Hoballah JJ, Taher AT, Jamali FR: Preoperative anaemia and postoperative outcomes in non-cardiac surgery: a retrospective cohort study. Lancet 2011, 378(9800):1396-1407.

8. Soerjomataram I, Louwman MW, Ribot JG, Roukema JA, Coebergh JW: An overview of prognostic factors for long-term survivors of breast cancer. Breast Cancer Res Treat 2008, 107(3):309-330.

9. Cianfrocca M, Goldstein LJ: Prognostic and predictive factors in early-stage breast cancer. Oncologist 2004, 9(6):606-616.

10. Voduc KD, Cheang MC, Tyldesley S, Gelmon K, Nielsen TO, Kennecke H: Breast cancer subtypes and the risk of local and regional relapse. J Clin Oncol 2010, 28(10):1684-1691.

11. Kandemir EG, Mayadagli A, Turken O, Yaylaci M, Ozturk A: Pre-treatment haemoglobin concentration is a prognostic factor in patients with early-stage breast cancer. J Int Med Res 2005, 33(3):319-328.

12. Boehm DU, Lebrecht A, Schmidt M, Siggelkow W, Lindner C, Litz A, Ulbrich E, Koelbl H: Prognostic impact of haemoglobin levels in breast cancer. Anticancer Res 2007, 27(2):1223-1226.

13. Singletary SE, Allred C, Ashley P, Bassett LW, Berry D, Bland Kl, Borgen PI, Clark G, Edge SB, Hayes DF, Hughes LL, Hutter RV, Morrow M, Page DL, Recht A, Theriault RL, Thor A, Weaver DL, Wieand HS, Greene FL: Revision of the American Joint Committee on Cancer staging system for breast cancer. J Clin Oncol 2002, 20(17):3628-3636.

14. Cordella C, Luebbers HT, Rivelli V, Gratz KW, Kruse AL: An evaluation of the preoperative hemoglobin level as a prognostic factor for oral squamous cell carcinoma. Head Neck Oncol 2011, 3:35.

15. Gilreath JA, Stenehjem DD, Rodgers GM: Diagnosis and treatment of cancer-related anemia. Am J Hematol 2014, 89(2):203-212.

16. Wilson J, Yao GL, Raftery J, Bohlius J, Brunskill S, Sandercock J, Bayliss S, Moss P, Stanworth S, Hyde C: A systematic review and economic evaluation of epoetin alpha, epoetin beta and darbepoetin alpha in anaemia associated with cancer, especially that attributable to cancer treatment. Health Technol Assess 2007, 11(13):1-202.

17. Thompson CA, Steensma DP: Pure red cell aplasia associated with thymoma: clinical insights from a 50-year single-institution experience. Br J Haematol 2006, 135(3):405-407

18. Dubsky $P$, Sevelda $P$, Jakesz R, Hausmaninger $H$, Samonigg $H$, Seifert $M$, Denison U, Mlineritsch B, Steger G, Kwasny W, Stöger H, Bartsch R, Stierer M, Taucher S, Fridrik M, Schippinger W, Greil R, Pötter R, Gnant M, Austrian Breast and Colorectal Cancer Study Group: Anemia is a significant prognostic factor in local relapse-free survival of premenopausal primary breast cancer patients receiving adjuvant cyclophosphamide/methotrexate/ 5-fluorouracil chemotherapy. Clin Cancer Res 2008, 14(7):2082-2087.

19. Peters-Engl C, Cassik P, Schmidt I, Denison U, Medl M, Pokieser W, Sevelda $P$ : Impact of haemoglobin levels during adjuvant chemotherapy on the 
survival of patients with primary breast cancer. Acta Oncol 2005, 44(2):129-133.

20. Vaupel P: The role of hypoxia-induced factors in tumor progression. Oncologist 2004, 9(Suppl 5):10-17.

21. Harrison L, Blackwell K: Hypoxia and anemia: factors in decreased sensitivity to radiation therapy and chemotherapy? Oncologist 2004, 9(Suppl 5):31-40.

22. Vaupel P, Mayer A, Hockel M: Impact of hemoglobin levels on tumor oxygenation: the higher, the better? Strahlenther Onkol 2006, 182(2):63-71.

23. Vaupel $P$, Mayer A, Briest $S$, Hockel M: Hypoxia in breast cancer: role of blood flow, oxygen diffusion distances, and anemia in the development of oxygen depletion. Adv Exp Med Biol 2005, 566:333-342.

24. Vaupel P, Harrison L: Tumor hypoxia: causative factors, compensatory mechanisms, and cellular response. Oncologist 2004, 9(Suppl 5):4-9.

25. Teicher BA: Acute and chronic in vivo therapeutic resistance. Biochem Pharmacol 2009, 77(11):1665-1673.

26. Harrison LB, Chadha M, Hill RJ, Hu K, Shasha D: Impact of tumor hypoxia and anemia on radiation therapy outcomes. Oncologist 2002, 7(6):492-508.

27. Vaupel $\mathrm{P}$, Thews $\mathrm{O}$, Hoeckel M: Treatment resistance of solid tumors: role of hypoxia and anemia. Med Oncol 2001, 18(4):243-259.

28. Vaupel $P$, Mayer A, Briest $S$, Hockel M: Oxygenation gain factor: a novel parameter characterizing the association between hemoglobin level and the oxygenation status of breast cancers. Cancer Res 2003, 63(22):7634-7637.

29. Vaupel P, Briest S, Hockel M: Hypoxia in breast cancer: pathogenesis, characterization and biological/therapeutic implications. Wien Med Wochenschr 2002, 152(13-14):334-342.

30. Hockel M, Vaupel P: Tumor hypoxia: definitions and current clinical, biologic, and molecular aspects. J Natl Cancer Inst 2001, 93(4):266-276.

31. Bos R, Zhong H, Hanrahan CF, Mommers EC, Semenza GL, Pinedo HM, Abeloff MD, Simons JW, van Diest PJ, van der Wall E: Levels of hypoxiainducible factor-1 alpha during breast carcinogenesis. J Natl Cancer Inst 2001, 93(4):309-314

32. Zhou J, Schmid T, Schnitzer S, Brune B: Tumor hypoxia and cancer progression. Cancer Lett 2006, 237(1):10-21.

33. Liao D, Johnson RS: Hypoxia: a key regulator of angiogenesis in cancer. Cancer Metastasis Rev 2007, 26(2):281-290.

34. Varlotto J, Stevenson MA: Anemia, tumor hypoxemia, and the cancer patient. Int J Radiat Oncol Biol Phys 2005, 63(1):25-36.

35. Vaupel $P$, Mayer A: Hypoxia in cancer: significance and impact on clinical outcome. Cancer Metastasis Rev 2007, 26(2):225-239.

36. Vleugel MM, Greijer AE, Shvarts A, van der Groep P, van Berkel M, Aarbodem $Y$, van Tinteren H, Harris AL, van Diest PJ, van der Wall E: Differential prognostic impact of hypoxia induced and diffuse HIF-1alpha expression in invasive breast cancer. J Clin Pathol 2005, 58(2):172-177.

37. Vaupel P: Prognostic potential of the pre-therapeutic tumor oxygenation status. Adv Exp Med Biol 2009, 645:241-246.

38. Rodgers GM: A perspective on the evolution of management of cancer- and chemotherapy-induced anemia. J Natl Compr Canc Netw 2012, 10(4):434-437.

39. Rodgers GR, Becker PS, Blinder M, Cella D, Chanan-Khan A, Cleeland C, Coccia PF, Djulbegovic B, Gilreath JA, Kraut EH, Matulonis UA, Millenson MM, Reinke D, Rosenthal J, Schwartz RN, Soff G, Stein RS, Vlahovic G, Weir AB 3rd: Cancer- and chemotherapy-induced anemia. J Natl Compr Canc Netw 2012, 10(5):628-653.

40. Khorana AA, Francis CW, Blumberg N, Culakova E, Refaai MA, Lyman GH: Blood transfusions, thrombosis, and mortality in hospitalized patients with cancer. Arch Intern Med 2008, 168(21):2377-2381.

doi:10.1186/1471-2407-14-844

Cite this article as: Zhang et al:: Impact of preoperative anemia on relapse and survival in breast cancer patients. BMC Cancer 2014 14:844.

\section{Submit your next manuscript to BioMed Central and take full advantage of:}

- Convenient online submission

- Thorough peer review

- No space constraints or color figure charges

- Immediate publication on acceptance

- Inclusion in PubMed, CAS, Scopus and Google Scholar

- Research which is freely available for redistribution

Submit your manuscript at www.biomedcentral.com/submit
C Biomed Central 